\title{
Pengembangan Kemampuan Literasi Kritis Melalui Pembelajaran Bahasa di SMP Sanjaya Girimulyo
}

\author{
Paulus Widiatmoko ${ }^{\# 1}$, Ignatius Tri Endarto ${ }^{\# 2}$ \\ \#Program Studi Pendidikan Bahasa Inggris, Universitas Kristen Duta Wacana \\ Yogyakarta, Indonesia \\ ${ }^{1}$ widiatmoko@staff.ukdw.ac.id \\ 2ignatius.endarto@staff.ukdw.ac.id
}

\begin{abstract}
Abstrak - Gerakan Literasi Sekolah sudah dicanangkan selama beberapa tahun oleh pemerintah. Namun dalam pelaksanaanya, program ini tidak lebih sebagai usaha penyediaan bacaan bagi para siswa di pojok baca atau perpustakaan yang tidak terintegrasi dengan pelajaran. Kegiatan ini mengacu pada taksonomi kemampuan membaca dan skema 3P GLS (Gerakan Literasi Sekolah), dengan fokus pada Pengembangan dan Pembelajaran kemampuan literasi kritis para siswa lewat mata pelajaran Bahasa. Masukan dari para guru dalam program sebelumnya untuk lebih mendekatkan program membaca dengan pembelajaran, memfasilitasi pembelajaran jarak jauh dengan aktifitas pembelajaran yang bermutu, serta kebutuhan untuk membekali generasi muda dengan kemampuan literasi kritis membuat kegiatan ini menjadi perlu dilakukan. Dalam pelaksanaanya, beberapa contoh materi bacaan yang merangsang kemampuan literasi kritis bagi siswa dikaji bersama dalam pelatihan perancangan aktifitas yang mengembangkan literasi kritis. Para guru memberikan tanggapan yang positif terhadap pelatihan ini dan program ini dianggap memberikan alternatif aktifitas kelas yang mendukung pembelajaran jarak jauh di masa Pandemi Covid19. Beberapa penyesuaian aktifitas perlu dikakukan mengingat lokasi sekolah yang berada di daerah pegunungan dan beragamnya kemampuan sosial ekonomi keluarga peserta didik. Diharapkan juga dengan program yang berlanjut ini para guru semakin memahami bagaimana pelaksanaan GLS (Gerakan Literasi Sekolah) dalam pembelajaran yang dicanangkan Kementrian Pendidikan sejak beberapa tahun lalu.
\end{abstract}

Kata kunci: GLS; Literasi Kritis; Pembelajaran Bahasa

Abstract-The government of Indonesia has launched the school literacy program for some years. However, its implementation this program has focused more on providing books in the literacy corner or library and has not comprehensively integrate the activities into courses. This community development program refers to the taxonomy of reading skill and the scheme of literacy manual of the school literacy program focusing on integrating students' literacy development into language courses. It has also been conducted in response to inputs from teachers in which literacy program to provide students with quality texts as reading material during the distance learning scenario. In its implementation, reading materials that nurture critical literacy were chosen

collaboratively with the teachers in mini workshops with the language teachers. The teachers responded positively, as this program could provide alternative activities to support distance instruction during Covid19 pandemic. Adjustments of

activities should be done considering the school is located quite remote in mountainous area and varied socio-economic status of the family. The ongoing program expectedly empower teachers to understand the implementation of school literacy program in their courses as has been launched by the ministry of education for some years.

Keywords-Literacy Program, Critical Literacy, Language Teaching

\section{PEndahuluan}

Uji literasi membaca dalam PISA 2009 menunjukkan peserta didik Indonesia berada pada peringkat ke-57 dengan skor 396 (dari skor rata-rata 493), sedangkan PISA 2012 menunjukkan siswa Indonesia berada pada peringkat ke-64 dengan skor 396 (dari skor rata rata 496). Sebanyak 65 negara berpartisipasi dalam PISA 2009 dan 2012. Pada tahun 2018 mereka meraih skor 371 dan ditengarai menjadi titik paling rendah dalam beberapa tahun terakhir(Harususilo, 2019; Halpern, 2014). Hal ini menjadi salah satu indikasi rendahnya kompetensi membaca peserta didik Indonesia. Sependapat, dengan hal tersebut Buku Panduan Gerakan Literasi Sekolah tingkat Sekolah Menengah Pertama memaparkan data serupa.[3]

Salah satu aspek penting peningkatan kompetensi membaca adalah aspek afeksi kegiatan tersebut. Aktifitas membaca sebagai sebuah kesenangan harus dimulai dan didorong dari Pendidikan dasar dan difasilitasi secara menyeluruh, baik di sekolah dan di lingkungan masyarakat 
termasuk di rumah. Hal tersebut tentunya bisa semakin diperkuat dengan integrasi secara sistematis melalui jalur pendidikan formal. Ketika membaca dilakukan secara extensive untuk kesenangan secara sukarela dan menyenangkan serta menjadi budaya dalam pelajaran, maka tidak hanya kemampuan membaca yang meningkat, akan tetapi juga kualitas Pendidikan. Day \& Bamford (1998) mengungkapkan bahwa praktik membaca harus dilakukan secara terus menerus melalui berbagai jalur atau kegiatan supaya pembelajar dapat menguasai kemampuan literasi yang mendukung mereka menjadi pembelajar sepanjang hayat. [4] [5]

Bagaimana mengembangkan literasi kritis? Ada berbagai teori tentang pengembangan literasi kritis, perspetif teori klasik Paulo Freire (1972) yang menyatakan bahwa membaca dengan kesadaran kritis dimulai dengan mengembangkan sikap ingin tahu terhadap dunia.[5] Hal ini diperlukan untuk menciptakan dan kembali menciptakan ide-ide, dan tidak hanya menggunakannya atau menyimpannya dalam "bank" memori mekanis pemaknaan secara literal. Senada dengan yang sudah disampaikan di bagian sebelumnya, Freire juga menyatakan bahwa pembaca bukan menjadi "object" dinamika belajar akan tetapi mereka menjadi pelaku aktif atau "subject" dalam pemaknaan sebuah teks atau diskursus. Paulo Freire menyatakan dengan jelas bahwa usaha untuk membebaskan siswa dari hegemoni dan dominasi kekuasaan bahkan perlu dilakukan dalam dunia Pendidikan dimana para guru harus mengajarkan cara memandang "dunia" dengan kritis. "banking model" harus diganti dengan "problem-posing model" yang akan membuat siswa dan guru lebih setara. Model ini disebut Freire bisa melawan oppression dengan memberdayakan manusia untuk lebih mampu "mempertanyakan" kondisi mereka dan mengedepankan "dialog".

Sejalan dengan hal tersebut James Paul Gee menyatakan bahwa literasi kritis membuat manusia menjadi "active questioners of the social reality around them". [6] Lebih lanjut disampiakan bahwa literasi kritis menggunakan aspek kogitif dan sosial literasi untuk membaca dunia dan menyadari setiap penindasan (oppression) serta melakukan perubahan yang menjadi perjuangan hak mereka. Aspekaspek kognitif, sosial, dan kritis ini disebut setara dan mempunyai tingkat kepentingan yang sama dalam memaknai literasi kritis secara penuh. Sousanis (2015) merekomendasikan kemampuan untuk melihat berbagai kejadian dari berbagai sudut pandang dan menganalisa bagaimana mereka berhubungan, dan mengetahui inti atau core dari masing-masing sudut pandang tersebut. [7]

Dalam mata pelajaran bahasa, kemampuan menjadi strategic reader lewat intensive reading sudah menjadi kompetensi utama pembelajaran. Hanya saja, untuk mendukung ekologi membaca dari kegiatan membaca sebagai sebuah kesenangan, pelajaran di kelas seyogyanya bisa merubah anggapan intensive reading sebagai kegiatan yang sulit, membosankan, dan tidak berguna menjadi mudah, menyenangkan, dan bermanfaat. Ini akan memotivasi para siswa untuk lebih banyak membaca dan berlatih. Selain itu membaca strategis juga perlu dipahami dan dilatihkan sebagai proses meaning making yang dilakukan secara aktif dan memerlukan respon, baik secara mental/kognitif atau secara fisik dengan berbagai luaran. Jika ini dilakukan para guru tidak lagi perlu secara khusus mempersiapkan drilling mengerjakan soal bacaan sebelum ujian nasional. Lebih penting lagi, fondasi mendidik generasi masa depan yang literat sudah dimulai dengan baik. Tentang hal ini (Halpern, 2014) menyatakan

"Students need to be able to understand concepts as tools, which can be used to solve real-world problems.....most importantly, students need to recognize threshold concepts".

Hal ini akan membuat mereka melihat dan memahami dunia dengan cara yang berbeda. [5]

SMP Sanjaya Girimulyo sebagai mitra kegiatan ini adalah gambaran sebuah sekolah terpencil di puncak perbukitan Menoreh, Kulon Progo, Yogyakarta. Menjalankan misinya untuk melayani mereka yang membutukan "sapaan" Tuhan, sekolah-sekolah di bawah Yayasan Katolik ini jauh dari kesan prestisius atau populer. Berbagai permasalahan dihadapi, bahkan hanya supaya untuk terus bertahan dan melayani. Relevan dengan kebutuhan sekolah, kegiatan pengabdian masyarakat ini bertujuan untuk mengintegrasikan program peningkatan literasi kritis dengan pembelajaran Bahasa Indonesia dan Bahasa Inggris. Diharapkan kegiatan ini bisa menjadi model bagi pengembangan literasi sekolah di luar mata pelajaran Bahasa dan mendorong kegiatan membaca secar sukarela bagi siswa.

\section{PROFIL MitRA}

SMP Sanjaya Girimulyo yang terletak sekitar $35 \mathrm{~km}$ di sebelah barat pusat kota Yogyakarta dikelola oleh Yayasan Santo Bernardus Keuskupan Agung Semarang. Sekolahsekolah di bawah Yayasan ini memang dipertahankan dan diusahakan terus berkembang karena pelayanan pada kaum "lemah, miskin, tersingkir".

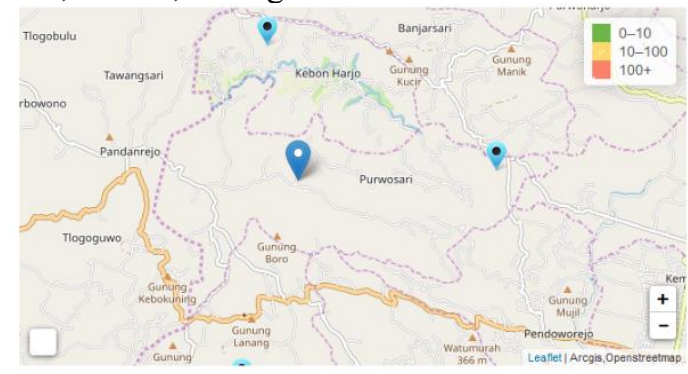

Gambar 1. Peta Lokasi SMP Sanjaya Girimulyo

Dengan jumlah siswa keseluruhan yang sedikit dan status guru sebagian besar Guru Tidak Tetap/GTT (tabel 1 
dan 2), kita bisa mendapatkan sedikit gambaran tentang sekolah ini.

TABEL I

DATA STATUS GURU DAN KARYAWAN

\begin{tabular}{|c|c|c|c|c|}
\hline GTT & PTT & GTT Y & GTY & Jumlah \\
\hline 9 & 1 & 1 & 1 & $\mathbf{1 2}$ \\
\hline
\end{tabular}

TABEL II

JUMLAH SISWA

\begin{tabular}{|l|l|l|l|l|l|l|}
\hline \multicolumn{2}{|c|}{ Kelas VII } & \multicolumn{2}{|c|}{ Kelas VIII } & \multicolumn{2}{c|}{ Kelas IX } & \multirow{2}{*}{ Jumlah } \\
\cline { 1 - 6 } L & P & L & P & L & P & \\
\hline 4 & 6 & 9 & 5 & 10 & 8 & $\mathbf{4 2}$ \\
\hline
\end{tabular}

Dalam hal prestasi akademis, siswa di sekolah ini juga bukan termasuk kategori unggulan secara akademik. Pada umumnya memilih sekolah ini karena lokasi yang dekat dengan tempat tinggal, atau memang tidak mempunyai pilihan belajar di sekolah lain karena keterbatasan biaya atau kemampuan akademis, atau pindahan dari sekolah lain karena kenakalan remaja. Padahal seperti kita tahu Undang Undang Dasar 1945 mengamanatkan hak semua warga negara untuk mendapatkan pendidikan.

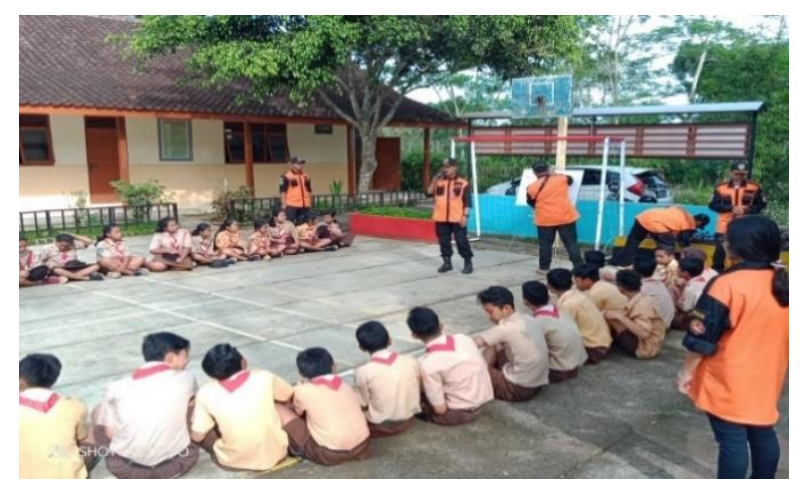

Gambar 2. Salah satu kegiatan sekolah

Sebagai sekolah yang dipertahankan untuk memberikan pelayanan, berbagai keterbatasan dirasakan menghambat penyelenggaraan kegiatan untuk memfasilitasi Pendidikan yang bermutu. Tidak bisa dipungkiri aspek kualitas sekolah dengan ketersediaan sarana-prasarana, sumber daya manusia pengajar dan pegawai, aspek finansial, proses pembelajaran, mutu lulusan dan lain-lain menjadi tantangan yang cukup rumit bagi sekolah ini. Akan tetapi harapan masih ada karena semangat para guru dan kepala sekolah serta wali murid yang mempercayakan para siswa belajar di sekolah ini.

\begin{tabular}{|l|c|}
\hline Proses Pembelajaran & 14 \\
\hline Rasio Siswa Rombel & 14 \\
\hline Rasio Siswa Ruang Kelas * & $\mathbf{7}$ \\
\hline Rasio Siswa Guru & $\mathbf{6 0}$ \\
\hline Persentase Guru Kualifikasi & 0 \\
\hline Persentase Guru Sertifikasi & 0 \\
\hline Persentase Guru PNS & 100 \\
\hline Persentase Ruang Kelas Layak
\end{tabular}

Gambar 3. Data Rasio Proses Pembelajaran

\section{PERENCANAAN DAN PELAKSANAAN PROGRAM}

Secara keseluruhan program ini dilaksanakan dalam beberapa pentahapan. Tahap analisa kebutuhan dimulai dengan mewawancara guru/relawan pengajar Mitra untuk mengetahui lebih dalam tentang pengajaran Bahasa dan halhal lain terkait dengan karakteristik siswa, kompetensi mereka secara umum, fasilitas, dan sebagainya. Hasil analisa tersebut menjadi masukan yang penting bagi tahap berikutnya, yaitu pemetaan peluang dan tantangan pelaksanaan kegiatan. Berbagai kemudahan yang akan memfasilitasi pelaksanaan maupun tantangan yang menghambatnya akan dipetakan dan menjadi sebuah rencana bagi rancangan pentahapan program ini.

Dalam tahap analisa kebutuhan, dilakukan wawancar dengan mitra, khususnya para guru Bahasa Inggris dan Bahasa Indonesia di sekolah tersebut. Hasilnya menjadi referensi bagi pelaksanaan program ini. Ada 3 orang guru yang diwawancarai dalam tahap ini. Bapak Anton (bukan nama sebenarnya), sebagai guru Bahasa Inggris yang juga merupakan kepala sekolah, Ibu Agnesi (bukan nama sebenarnya) sebagai salah satu guru Bahasa Inggris kelas 9, dan Ibu Ririn (bukan nama sebenarnya) sebagai wakasek bidang akademik sekaligus pengajar Bahasa Indonesia.

Secara singkat dapat kami laporkan dari hasil wawancara tersebut sebagai berikut. Bapak Anton memberikan gambaran tentang kondisi pembelajaran di masa pandemi dan tantangan terkait minat baca para siswa. Disampaikan oleh beliau bahwa pembelajaran dari rumah (BDR) selama pandemi di sekolah SMP Sanjaya dilakukan dengan beberapa skenario. Bagi yang mempunyai akses internet materi pembelajaran bisa diakses dengan media WA group kelas, akan tetapi bagi mereka yang terkendala sinyal serta akses internet akan dikunjungi guru secara berkala. Kondisi geografis rumah siswa yang cukup sulit di pegunungan Menoreh menjadi tantangan tersendiri bagi para guru. Pembelajaran bauran dengan percobaan tatap muka sempat dilakukan selama sebulan di bulan April-Mei, akan tetapi setelah pemberlakuan PPKM Darurat, hal 
tersebut dilarang. Tentang minat baca, diakui oleh beliau bahwa minat baca siswa disana masih sangat rendah. Beberapa siswa dari kalangan yang mampu, malah lebih menyukai berinteraksi dengan game dan gadget. Berkenaan dengan pelaksanaan, Bapak Kepala sekolah dalam koordinasi pertama di bulan April menyarankan pelaksanaan kegiatan ini di semester baru, setelah bulan Juli 2021 karena sekolah sedang mempersiapkan pengajuan borang akreditasi.

Ibu Agnesi dan Ibu Ririn secara terpisah menyatakan persetujuan atas pendapat Bapak Anton tentang tantangan pembelajaran di masa pandemik di sekolah tersebut. Di tengah keterbatasan fasilitas dan tantangan geografi, mereka tetap berusaha sebisa mungkin menjangkau para siswa. Diakui memang bahwa ada siswa yang tidak mau peduli bahkan untuk kegiatan wajib yang menjadi komponen penilaian belum tentu membuat siswa tersebut mau melakukannya. Mereka menyarankan pelaksanaan kegiatan pengabdian ini diberikan pada siswa kelas 7 dimana motivasi mereka relatif baik dan pembelajaran kelas belum difokuskan pada persiapan ujian nasional, seperti halnya kelas 9. Dengan saran tersebut maka kegiatan ini difokuskan pada pengembangan kemampuan literasi kritis siswa kelas 7. Kombinasi pembelajaran jarak jauh dan kunjungan ke beberapa rumah siswa (yang terkendala sinyal) disarankan oleh para guru. Hal ini sudah dilakukan selama beberapa bulan untuk memfasilitasi pembelajaran di masa pandemi.

Sehubungan dengan kemampuan siswa kelas 7, maka pemilihan materi bacaan dilakukan cara melakukan analisa kebahasaan materi pelajaran Bahasa kelas 7 dibandingkan dengan pilihan topik dan tingkat kesulitan bacaan. Oleh karena para siswa belum mendapatkan Bahasa Inggris di SD sebagai pelajaran wajib, maka bacaan bilingual (Bahasa Inggris-Indonesia) dipilih buku cerita jenis Fabel, Legenda Indonesia, dan Cerita Nilai-Nilai Moral. Para guru mitra berpendapat bahwa buku cerita klasik internasional seperti Cinderella, Pinokio, dan sebagainya dirasa kurang sesuai dengan tingkat kemampuan siswa kelas 7 dan kurang bsia memfasilitasi pembelajaran bilingual Bahasa InggrisIndonesia.

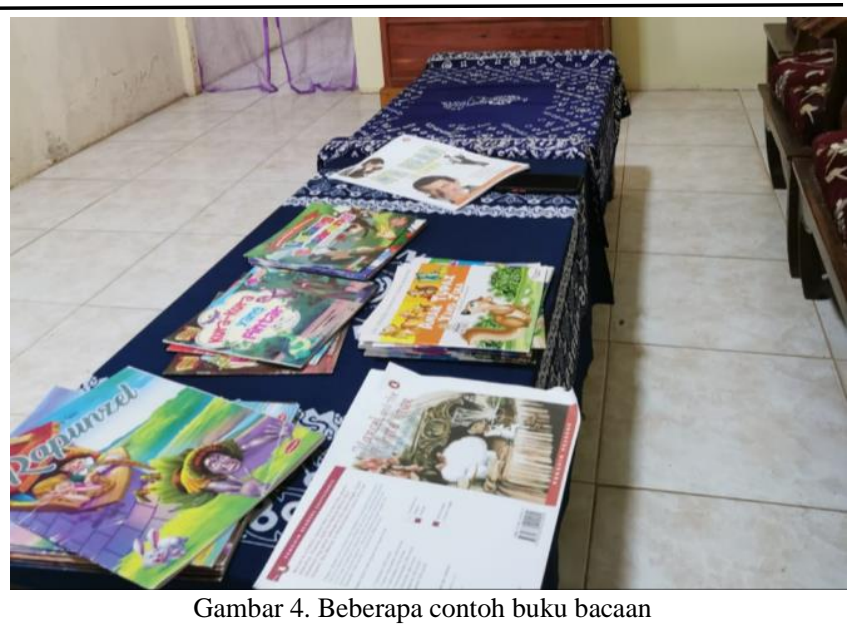

Berkenaan dengan pilihan tema buku bacaan oleh para guru, dimana tema cerita rakyat dan legenda Indonesia dwi bahasa (Inggris dan Indonesia) lebih dipilih, maka hal ini sesuai dengan teori pembelajaran membaca tentang konsep schemata. Dalam konsep ini dijelaskan bahwa:

"Reading comprehension is a function of the nature of the text itself and of the extent to which the reader possesses, uses, and integrates pertinent background knowledge, or schemata. Schemata can be loosely defined as patterns which represent the way experience and knowledge are organized in the mind." [6]

Schemata dalam aktifitas membaca bisa dikatakan sebagai pengetahuan yang sudah didapat oleh siswa sebelum membaca teks. Pengetahuan ini sangat erat hubungannya dengan pengalaman, lingkungan, proses interaksi masyarakat, dan ruang lingkup masyarakat para siswa. Oleh karenanya pemilihan teks yang bersifat local kedaerahan dalam kegiatan ini sesuai dengan teori schemata. Dengan memahami teks, siswa lebih bisa melihat relevansi isi dan pesan untuk diterapkan dalam kehidupan nyata mereka.

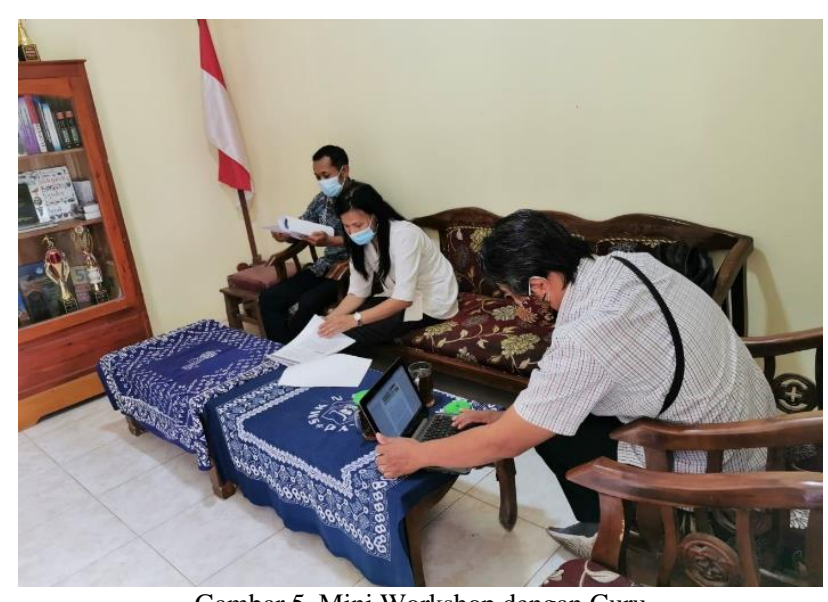

Gambar 5. Mini Workshop dengan Guru 
Referensi utama pelaksanaan yang dipakai dalam kegiatan ini adalah buku panduan GLS Sekolah Menengah Pertama yang diterbitkan oleh Kemdikbud. Dalam penerapannya dilakukan berbagai penyesuaian terutama dalam hal skenario kegiatan peningkatan literasiyang berbasis pada pembelajaran kelas. Aktifitas kelas dan metode yang dipakai menyesuaikan perencanaan kegiatan kelas selama 1 semester. Sebagai contoh dalam pelajaran bahasa Indonesia, integrasi kegiatan ini dengan materi cerpen dilakukan pada saat topik atau tema cerpen sudah waktunya diajarkan menurut rencana pengajaran kelas 9 .

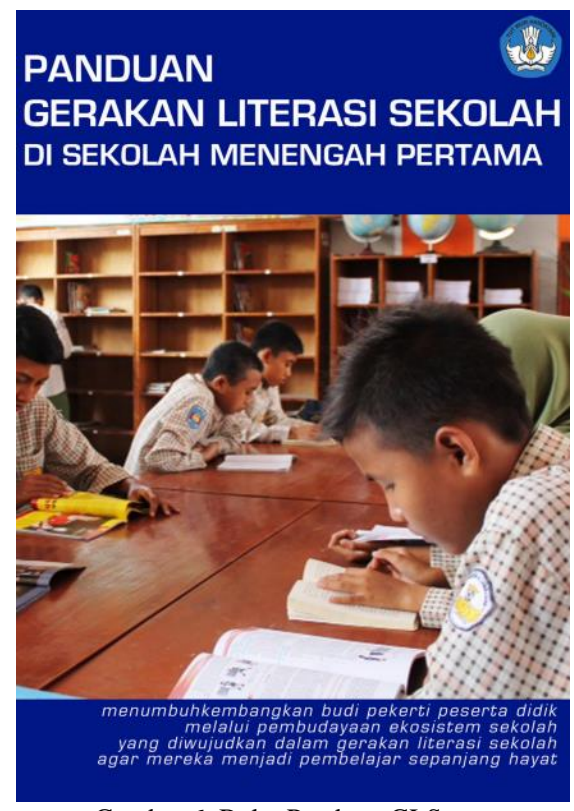

Gambar 6: Buku Panduan GLS

Buku panduan kegiatan literasi sekolah terbitan pemerintah bisa dipakai sebagai pemantik terselenggaranya kegiatan tersebut di sekolah. Akan tetapi dalam pelaksanaanya perlu disesuaiakn dengan berbagai hal. Pertama, kondisi sekolah beserta fasilitas pendukungnya. Kedua, kegiatan di luar pembelajaran. Ketiga, perspektif pengajaran membaca yang diyakini dan akan diterapkan di sekolah. Terakhir, teori tentang literasi dan pengembangannya.

Berkenaan dengan teori literasi, perspektif bahwa literasi adalah multidimensi perlu diperhatikan oleh sekolah. Teori literasi multidimensi dalam [7] menyatakan keterkaitan literasi dengan dengan berbagai bidang (linguistik, kognitif, sociocultural, dan developmental) seperti dalam gambar berikut.

TABEL III

LITERASI MULTIDIMENSI

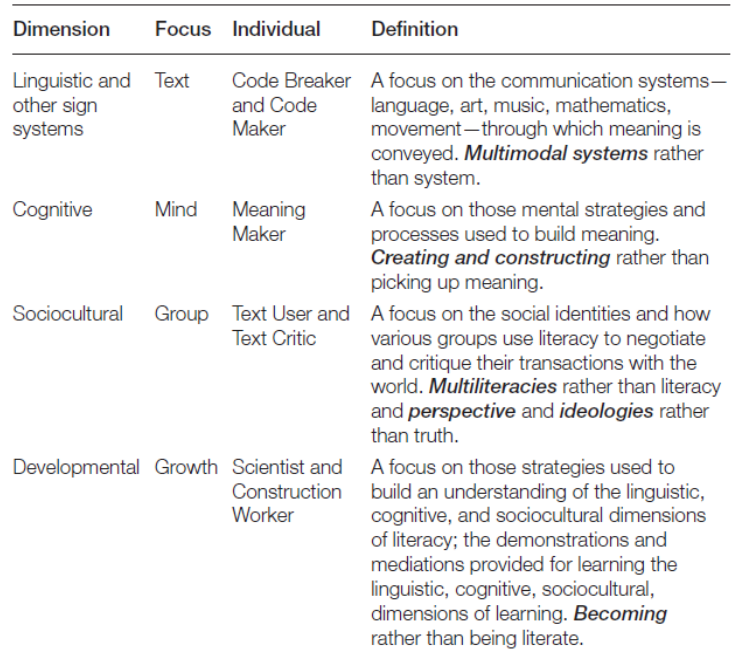

Implikasi hal di atas dalam program ini adalah bahwa pengembangan literasi bisa diterapkan dalam berbagai aspek perkembangan siswa sebagai individu pembelajar sampai pada siswa sebagai komunitas sosial. Artinya kegiatan ini bisa diarahkan tidak hanya kemampuan literasi indivisu, namun juga peningkatan kemampuan siswa sebagai sebuah komunitas yang literat. Ini memang sebuah tujuan ideal masa depan yang perlu diwujudkan dalam beberapa pentahapan

Beberapa poin penting sebagai refleksi kegiatan ini adalah pertama, beberapa scenario pelaksanaan perlu direncanakan untuk mengantisipasi kondisi tidak terduga seperti pembatasan belajar masa pandemic. Kedua, melibatkan mitra pengabdian dalam perencanaan dan pembicaraan teknis pelaksanaan merupakan hal yang penting demi kelancaran program. Ketiga, peningkatan literasi siswa harus didahului dengan membangun paradigma guru [11] tentang literasi dan pengembangannya serta integrasinya dalam pembelajaran.

Kegiatan pengabdian masyarakat ini memang belum sampai tahap akhir pelaksanaan. Dalam perencanaan selanjutnya, program ini akan diteruskan dengan pelatihan lanjutan bagi para guru untuk melaksanakan pembelajaran literasi kritis bagi para siswa. Selanjutnya, integrasi materi pelatihan dan buku cerita dalam pembelajaran Bahasa (Inggris dan Indonesia) di sekolah tersebut oleh para guru dan tim pengabdi. Di tahap akhir tim pengabdi akan melakukan evaluasi dan publikasi hasil pengabdian masyarakat.

\section{KESIMPULAN}

Kegiatan peningkatan kemampuan literasi sangat diperlukan sejak Pendidikan dasar. Integrasi kegiatan ini dengan pelajaran adalah salah satu upaya untuk memastikan kegiatan kurikuler tidak terpisah dari esensi membaca sebagai usaha peningkatan kiterasi kritis.

Kementrian Pendidikan telah menerbitkan buku panduan penerapan Gerakan Literasi Sekolah (GLS) untuk berbagai 
tingkatan Pendidikan mulai dari sekolah dasar sampai sekolah menengah atas. Berbagai buku modul penerapan juga telah diterbitkan untuk diterapkan dalam pembelajaran kelas maupun sebagai panduan kegiatan literasi sekolah itu sendiri. Pihak sekolah seyogyanya memanfaatkan panduan dan buku modul GLS, dengan penyesuaian seperlunya, untuk meningkatkan kemampuan literasi kritis para siswa.

Program peningkatan literasi di SMP Sanjaya Girimulyo telah mencoba menerapkan metode partisipatif mulai dari analisa kebutuhan dan observasi keadaan sekolah, terutama pembelajaran di masa pandemi, untuk melaksanakannya. Kegiatan ini telah menghasilkan rumusan kegiatan dan pemilihan materi bahan bacaan dengan kolaborasi para guru bersama tim pengabdi. Pemilihan bacaan tentang cerita rakyat, legenda, fabel, dan buku dwibahasa IndonesiaInggris dilakukan untuk memastikan muatan lokal dan kebijaksanaan lokal terwariskan ke para siswa. Kegiatan ini masih akan berlanjut sampai akhir tahun dengan penerapan lebih lanjut.

\section{UCAPAN TERIMA KASIH}

Program kegiatan pengabdian masyarakat ini didukung oleh Lembaga Penelitian dan Pengabdian Masyarakat (LPPM) Universitas Kristen Duta Wacana. Sampai saat publikasi ini, program yang masuk dalam skema Ipteks bagi Masyarakat (IBm) ini masih akan berlangsung sampai bulan November 2021.

\section{DAFTAR PUSTAKA}

[1 Y. E. Harususilo, "Kompasiana.com," Kompas, 4122019.

] [Online]. Available:

https://edukasi.kompas.com/read/2019/12/04/13002801/skor-pisaterbaru-indonesia-ini-5-pr-besar-pendidikan-pada-era-nadiemmakarim?page=all. [Accessed 49 2021].

[2 D. F. Halpern, Thought and knowledge : an introduction to critical ] thinking, New Jersey: Lawrence Erlbaum Associates Publishers., 2014.

[3 P. Retnaningdyah, Panduan Gerakan Literasi Sekolah di Sekolah

] Menengah Pertama, Jakarta: Direktorat Pembinaan Sekolah Menengah Pertama, Dikdasmen, Kemdikbud, 2016.

[4 R. R. D. Julian Bamford, Extensive Reading in the Second

] Language Classroom, New York: Chambridge, 1998.

[5 H. M. A. M. Seifi L, "The effect of information literacy instruction

] on lifelong learning readiness," Ifla Journal, vol. 46, no. 3, pp. 259270, 2020

[6 P. Freire, Freire, P. (1972). Pedagogy of the oppressed., New York: ] Herder and Herder, 1972.

[7 J. P. Gee, Literacy and education, New York: Routledge. Hadley, ] Mass: Bergin \& Garvey, 2015.

[8 N. Sousanis, Unflattening., Cambridge, MA: Harvard University ] Press, 2015.

[9 R. Land, J. Meyer and J. Smith, Threshold concepts within the ] disciplines, Rotterdam: Sense Publisher, 2008.

[1 J. L. Meurer, "Schemata and Reading Comprehension. [online].," 0] ResearchGate, 3 May 2008. [Online]. Available:
https://www.researchgate.net/publication/49618002_Schemata_and _readingcomprehension_Schemata_and_readingcomprehension. [Accessed 2021 Agugust 2021].

[1 S. Kucer, Dimension of Literacy, New York: Taylor and Francis, 1] 2009.

[1 N. S. Kelana, "Siedoo," 19 November 2019. [Online]. Available: 2] https://siedoo.com/berita-26622-perlu-dipahami-guru-berikut-tigatahap-gerakan-literasi-sekolah/. [Accessed 1 November 2021]. 